\title{
The Application of Abraham Maslow's Hierarchical Theory in Islamic Education Learning at Tamanan Elementary School Bantul
}

\author{
M. Afiqul Adib \\ Universitas Islam Negeri Sunan Kalijaga,Yogyakarta, Indonesia \\ 19204010117@student.uin-suka.ac.id \\ Suyadi \\ Universitas Islam Negeri Sunan Kalijaga, Yogyakarta, Indonesia
}

Suyadi@uin-suka.ac.id

\begin{abstract}
This research aims to determine the application of Abraham Maslow's hierarchy of needs theory in Islamic education learning at Tamanan Elementary School Bantul to help teachers understand the desires of their students in learning. The method used is field research, then it is integrated with various related sources. The results of this study are: a) Maslow's hierarchy of needs theory b) Application of Abraham Maslow's Hierarchy of Needs (Humanistic) Theory in Islamic Education learning at Tamanan Elementary School. The conclusion of Maslow's theory of needs aims to make individuals as good human being as possible. This will be very useful in the application of learning so that students can understand themselves and their environment. The students who have reached this level will do various things in order to maximize their potential so that learning can be effective.
\end{abstract}

Keywords: Theory of needs; Abraham Maslow; Islamic Education 


\begin{abstract}
Abstrak
Penelitian ini bertujuan untuk menjelaskan penerapan teori hirarki kebutuhan Abraham Maslow dalam pembelajaran PAI di SDN Tamanan, Bantul. Guna membantu guru memahami keinginan muridnya dalam pembelajaran. Metode dalam penelitian ini yakni field research atau penelitian lapangan, kemudian diintegrasikan dengan berbagai sumber terkait. Hasil penelitian ini berupa: a) Teori Hirarki Kebutuhan Maslow b) Aplikasi Teori Hirarki Kebutuhan (Humanistik) Abraham Maslow Dalam Pembelajaran PAI di SDN Tamanan. Kesimpulan Teori kebutuhan Maslow bertujuan untuk menjadikan individu sebagai manusia sebaik mungkin. Hal ini dalam penerapan pembelajaran akan sangat berguna agar siswa bisa memahami dirinya dan lingkungan. Siswa yang sudah mencapai taraf tersebut akan melakukan berbagai hal dalam rangka memaksimalkan potensi yang dimiliki sehingga pembelajaran dapat efektif.
\end{abstract}

Kata kunci: Teori Kebutuhan; Abraham Maslow; PAI

\title{
A. Introduction
}

Education is predicted to be the vanguard in solving and answering existing problems, starting from morals, profession, welfare, economy, health, etc. Absolutely, the success of learning in formal schools has gone through various problems. Whether these problems are directly related to learning or the success of learning, especially Islamic Education, it is necessary to admit that it is not only determined by one aspect but many things. It is complex (Amalia 2019).

Since the Islamic religion that was spread by Walisongo began to appear in this archipelago, PAI has continued to grow and develop progressively. The ideals of education are to educate the nation's life. It means that a nation can live smartly and overcome various problems. In Islam, it is called by kaffah human. It fulfills the duties of the caliph on earth.

Passive learning still becomes a problem in the academic community. This passive learning method is considered not optimal to solve the existing problems in life. In its application, it should emphasize the relationship between the teacher and the desires of students. It is not just teacher beliefs about what students should do (Umam 2019). Because students are individuals who have the right to develop their potential.

Islamic education still can be controlled by knowing rather than doing. This can be seen from the educational practices that exist in various Islamic educational institutions, such as Islamic boarding schools, Islamic schools, and Islamic universities. So far, the existing 
teaching and learning process still prioritizes the mastery of knowledge under the authority of teachers, rather than the development of the student and the activities to build the character of independence (Assegaf and Dkk. 2007).

PAI educators tend to teach normative problems that are only white and black. It is not taught about other colors, for example, gray or others. So, they teach about law. When one activity is considered as "not halap", so it is "haram" (Umam 2019). Delivering exclusive material makes students' have a good understanding (Zainab 2020). Efforts in maximizing the potential of students need a truly targeted method that not only spreads knowledge but also values (Muamanah and Suyadi 2020)

One of the efforts that have been made since decades ago is to improve learning methods, such as grammar methods, reading methods, integrated methods, thematic methods, quantum methods, participatory methods, contextual methods, and others (Khamda and Dkk 2012). Some methods that are rarely used are those that are humanistic. If this studentcentered approach is applied well, it will make good learning Islamic education. This humanistic learning concept makes students curious. Students also have the right to be given knowledge when they want it, not to be bombarded with the knowledge they do not expect.

Discussing the humanistic approach, of course, cannot be separated from Abraham Maslow's theory of needs. Explicitly, this theory does not discuss specifically Islamic education, but this theory is very useful for perfectly understanding students. One of the main components of the success of education is the quality of educators. If educators can understand what is needed by students, learning will be very optimal. To achieve this optimization, of course, comprehensive insight is needed. So, it is not enough just to understand the theory of teaching, but also to understand the subject being taught.

If educators want to succeed in the learning process, they have to understand the basic concepts of humans first. How can a student learn if his basic needs are not fulfilled? This is same as a question; how can educators teach if their basic needs are not sufficient? Therefore, understanding Maslow's concept of a hierarchy of needs is very important. This concept is useful for students and educators.

If this understanding is achieved, the learning direction will become clearer. Learning will lead to clear targets, not what has been achieved or what does not need to be achieved. This kind of concept is indispensable in Islamic Education. As is well known, Islamic Education is very rich in material but the implementation is quite weak. So, it needs to be 
evaluated. This method can be used as a reference for educators to determine learning steps, starting from planning, implementation, and evaluation.

Throughout the researcher's search, several studies have a close point of view with this study. The first is a study written by Aam Amalia on the application of Maslow's Needs Theory in Arabic Language Learning. Second, an article by Suprihatin entitled Humanistic Approach in Islamic Education Curriculum Development. Third, Budi Agus Sumantri and Nurul Ahmad's research regarding Humanistic Learning Theory and Its Implications for Learning Islamic Religious Education. The similarity of the studies with this study is in the humanistic theory used. Meanwhile, the new topic raised by the researcher as a differentiator is a subject and basic theory used, and the point of view in study analysis.

This study analyses Tamanan State Primary School, Bantul. The study time is Tuesday, Dec 15th 2020 until the end of December 2020. The subjects of this study were 5 teachers, consisting of 2 Islamic Education teachers (including researchers), 1 curriculum time, and 2 classroom teachers. In addition, it also involves 2 classes consisting of 26 and 25 students of Tamanan State Primary School, Bantul. This research belongs to the qualitative category. This is a comprehensive study to understand the environment (such as behavior and phenomena) experienced by the object of study which is explained through descriptions.

\section{B. Discussion}

\section{Abraham Maslow's Theory about Needs (Humanistic)}

According to Robert, who was quoted by Aam, humanism is a very broad diction. It can be interpreted in many conditions. Humanism in religious discourse means distrust of elements of ghoib or power such as baraka, and so on. Humanism considers that everything which can be proven academically is logical. Besides, this word can also be interpreted as a belief to everything is from God. In contrast, humanism in the academic sphere has a deep discussion about culture (Amalia 2019).

This thought has always done well by appreciating every individual's innermost ability that has been given by God. The dynamism of the times creates ever-changing problems and solutions. Likewise, when it comes to education, the solutions are always evolving and adjusting to the pace of change. Humanism can be ready to make solutions (Rachmahana 2008).

For humanistic theorists, the learning sequence runs and returns to the individual. Among the behavioral, cognitive, and constructivist learning theories, this theory is a renewal 
theory in viewing problems. It can be concluded that this theory focuses more on changing thinking rather than focusing on conventional learning materials (Siregar and Nara 2011).

The Humanistic theory sees the learning process as intentional to increase potential. Therefore, humanism is closer to philosophy because it is more concerned with thinking, rather than educational psychology. This science has a view to treating students as independent subjects who determine their own life goals. Students are responsible for the survival of their lives and their environment (Arbayah 2013). This theory views that humans have a level of need. If their basic needs can be met, it will arise the upper level of needs. This will hold until they can achieve their self-actualize. Maslow's theory of needs includes: (Santrock and W. 2009).

\section{Physiological Needs}

This need is primary for everyone. This need concerns basic things such as clothing, food, shelter as well as biological needs. Physiological needs are the basic needs of all human beings (Iskandar 2016). When these basic things are fulfilled smoothly then other needs will arise to be fulfilled. Logically, how can humans think of self-development if every night there is always a thought that "what will I eat tomorrow?" (Goble 1987). This also explains why political figures such as Ma'ruf Amin, Donald Trump, Joe Biden, and so on, even aspire to pursue a political career even though they are entering their old age. One of the reasons is their physiological needs have been met, so that, he can achieve other needs.

In Islamic Education learning, before deciding which learning method is suitable, the teacher should understand the commitment of needs which is the basis of motivation in achieving educational goals, especially Islamic Religious Education. Fulfilling the basic needs of student subjects is prioritized because it has a major impact on student learning outcomes. That is why teachers are encouraged to contribute to making the easier method for students to achieve the things needed by students.

Several activities aim to meet the physiological needs of Islamic education. These can be used as an effort to meet the basic needs of students in studying Islamic education, including loving Islamic education as a learning need. The success of meeting needs in learning is the result of cooperation in all aspects, from the teacher's ability to the methods used by teachers to teach. The look and decor of the study room also matter. In essence, all aspects must be real and lead to a happy learning goal (Chatib 2013). 


\section{Safety and Security Needs}

This demand is demand after the physiological demand is fulfilled. This is a safety request. The person who thinks he is insecure, he needs good rules and tries to stay away from unknown things and dangerous situation. A safety need describes a willingness to feel safe to get rewarded and stay away from threats, accidents, bankruptcy, disease, and suffering. In organizing, this demand is seen in the interests of job and position security, trade unions or labor unions, work environment security, salary bonuses, pensions, investments, etc. (Mujib and Suyadi 2020).

If students can learn Islamic education in a useful way, they will get the need for a sense of security. This means that educators need to teach well, in the sense that it is in accordance with the learning objectives that are happy, not dangerous. Teaching is an art that every teacher can be technically different but its main goal is same. The art of teaching is also related to good conditioning, so that, students are ready and in good condition, so that, the condition of learning will be safe, comfortable, effective, and efficient.

Teachers must accommodate physical and psychological needs for security. Students must be safe from crimes and threats that are psychologically dangerous, such as bullies or other people's nagging, being belittled, and humiliating without explanation. Class safety is a guarantee for students. Safety is the responsibility of the teacher, as stated in the guidelines regarding learning rules which state that every learning should have a fairly high level of comfort and safety.

\section{Social Needs}

After a few steps in the hierarchy above are fulfilled, then, the focus of every individual is having friends, love, and acceptance. Someone will be happy when everyone likes him. He tries to meet their social needs by reducing the burden on formal and informal groups in working with teammates (Mujib and Suyadi 2020). Fulfillment of this social need is important, so that, he becomes a member of the social group in their environment.

Social needs, including the need to belong, trust, love, bond, etc., can greatly influence learning. This is because truly happy students will more easily understand the material. They do not have the burden of overthinking. However, these cases are rarely observed and considered insignificant by most teachers. If the teacher provides stimulation on how students interact with friends and the classroom environment, then the teacher can meet the social needs of students and can help them to understand the material presented. 


\section{Appreciation Needs}

This demand is related to the desire to get a positive impression, attention, recognition, and appreciation of his fellow countrymen. When an organization appreciates its work, there will be a sense of recognition, responsibility, and pride that will help the actualization process (Mujib and Suyadi 2020). Ego fulfillment is prestigious in itself because it challenges and fosters responsibility. Student achievements should be appreciated. Respecting students' goals allows them to continue to develop their achievements. Maslow suggests that every individual desire the prestige of society for the hegemony of self-confidence.

Therefore, teachers need to have observation skills on learning to find out what deficiencies and needs of the students. The teachers also have to understand how to respond, how to cover up the shortcomings of students, and so on. Teachers must know the direction of encouragement or appreciation of student performance. The irony that occurs is students feel unsatisfied with the response of the teacher who seems to think that the individual is helpless or unqualified. Unfortunately, some teachers even think that they have no potential at all. The response is often made on the individual's failure in one subject.

\section{Self-Actualization Needs}

This development is a right of personal development, including the needs of the highest level. These needs include developing one's talents and potential, maximizing basic abilities, and their development. This need can be achieved if students have many opportunities to try and explore various things and activities, which can help students find valuable things that can help them in self-actualizing (Mujib and Suyadi 2020).

Actualization fulfillment is the fulfillment they want to produce. Then, the results can be seen by other people with their potential. Maslow also calls self-actualization with the addition of self-qualities. To achieve this, other needs must be met (Amalia 2019). This need also depends on a conducive environment, in the form of teachers, friends, family, and so on (Mujib and Suyadi 2020). One of the advantages of self-actualizing people is they have a more complete self-esteem ability. This kind of person has very good intrapersonal abilities, and can respect other people well enough, so, they can socialize or make friends with anyone, even those who are older than them (Maslow 1970).

\section{The Purpose and Scope of Islamic Education Learning}

In essence, Islamic education is the development of all human potential and the arrangement of behavior based on Islamic values, the possession of a positive spiritual soul, emotional stability, moral awareness, sufficient insight, and life-relevant skills to help solve 
problems, so that they become human, so, a human can be the caliph fi al-Ardl (Maragustam 2018). In line with it, according to Azyumardi Azra, Islamic education is about everything that exists in Islam. Therefore, the purpose of Islamic education is also an indicator of becoming a caliph (Azra 2012).

When examined from a fundamental point of view, it shows that Islamic education aims to foster and develop the potential of mankind to achieve its goal of appearing as a human being in the world to the fullest possible and realizing the mission of the Khalifah Allah. This is a hidden ability that needs to be explored because it has been implanted since it was created. This is about physical or spiritual (Mappasiara 2018). So, it can be concluded that the purpose of education in Islam reflects the task of being a caliph, namely seeking the pleasure of Allah, both actions related to oneself or others.

Therefore, to realize the goals of Islamic education in kaffah, effective and efficient efforts are needed. The approach needed to use is humanistic, so that, the potential of each individual is maximally explored and honed. In the educational process, students are not only objects but also subjects. Supposedly, students are involved in the preparation of learning. Also, learning should be based on student character. Some of the potential aspects of students include (1) needs, (2) space, (3) intelligence, (4) personality (Ramaylus 2008).

In line with that, Syamsul Nizar quoted by Ramayulis explained the character of students in accordance with humanistic theory: (1) Students are not miniature adults who must be equated from thinking to life goals. they have the right to decide their own goals; (2) Students are like humans in general who have a continuous development phase; (3) Students are still human beings, who have the potential to do various things dynamically; (4) the biological body of the student is just like humans in general which has a body structure and a spirit (Ramaylus 2008).

Islamic education understands students based on an understanding of the nature of human events. It makes them sublime creatures from God. The dignity of man must be respected. He must be treated differently from other creatures. If no education and guidance truly include physical and spiritual formation, physical, and spiritual, it is impossible to manifest glory itself through self-control (Muhaimin 2002).

The Islamic education dimension includes all the points of divine revelation conveyed by the prophet Muhammad which is then integrated with morals and influences the times including thoughts, feelings, behavior, and personality formation which are ultimately reflected in the form of a human being as a Muslim in Islamic teachings (Mappasiara 2018). 
Islamic education refers to the potential for human existence. This potential in the view of Islam is called fitrah. If it is made clear, this potential is everything already present in human creation, which could develop if it was developed. This can be very useful for solving problems faced by mankind as well as being used as a means of service which is defined as ma'rifatullah. Therefore, the development of fitrah must lead in a clear direction.

\section{The Application of Abraham Maslow's Hierarchy of Needs (Humanistic) Theory in Islamic Education Learning at Tamanan Elementary School}

The application of Maslow's theory in education needs to be examined. According to Maslow, teachers cannot directly relate an incident to the child until he understands that there may be a process that cannot meet the needs of children who need to know and understand. Therefore, teachers should not immediately blame students before they know what is the root of the problem, because it is impossible for students to mess up without problems in life (Rachmahana 2008).

Humanistic theory can be applied to Islamic education and learning. When planning to learn, it should be adjusted to the things that are needed. Like when cooking, you have to know who is going to eat the food because it could be that the food is delicious for some or not. So, it must be adjusted, so that, students can learn freely and choose the direction of development (Umam 2019). In terms of learning, Maslow's self-driving theory is used as a reference for the development of educational human resources. Encouraging learning can stimulate student potential. This builds motivation, and in its context, a comprehensive theory of discussion of the human subject is required (Sumantri and Ahmad 2019).

To realize the concepts that exist in humanistic concepts, it is necessary to pay attention to the rationale and thought: (1) Explain the purpose of explanation first before presenting the material. This is an alarm so that students have an interest and understand what the benefits are when learning about it; (2) Often applying learning with life or knowledge that is manifested that learning what is needed in society. You can also use games where the direction is interaction and creation; (3) the principle of the teacher is noticed and imitated. It means that the teacher must be ushwah for his students. It is because many teachers can be uswah but most of them apply improper methods.

The learning process from a humanistic perspective is the development of personality, spirituality, behavior, and the ability to understand social phenomena. The sign of the success of this application is students will be excited, passionate, or enthusiastic about various things that they have to do with learning in school (Suprihatin 2017, 94). The results showed that 
Islamic education learning at State Elementary School applies several models and methods that are in accordance with the concepts of Abraham Maslow's theory about needs, including:

Before starting the teaching process, Islamic education teachers will analyze the personalities and needs of students to help them understand the material well. This method also aims to ensure parallel operation of the theory and conditions at the site. The Islamic education learning process is based on student needs. So, observation is very important for this method. Observation will determine the development, desire, and spirit of students in learning. The ability of an educator is the ability of a person to carry out his duties responsibly and correctly. Professional teachers have a passion for learning. They can teach and adapt to student needs (Amalia 2019).

The method used in learning shows a shift from being very teacher-centric to be student-centric. This method can encourage students to take an active role in Islamic education and learning. For example, the students can actively debate, solve problems for themselves and their friends even in the environment, they also actively seek information from existing technology, and they also actively ask for material that the teacher does not understand.

In education, there is a very important keyword. It is learning. Learning is an activity to digest insights, knowledge, skills, and anything that can be applied in life. Learning is not only defined as the development of cognitive abilities but also develops all the potential bestowed by God. Then, that potential can be developed if education is in accordance with what students want. It is because a humanist education is very feasible to be applied (Baharuddin and Wahyuni 2007).

In this State Elementary School, students can play an active role. They feel happy and comfortable. Their enthusiasm in the learning process makes them feel free to discuss, so that, they are spirit to achieve achievements. This makes them keep their spirit also to learn many fields. Hopefully, there is an accordance between Islamic knowledge and general knowledge.

In this study, it can be seen that when students express their own opinions about a subject, the teacher appreciates what students say and will not underestimate it. Humanist educators are those who do not pressure the environment where students live. So, students will feel safe and comfortable along with their studies. In this way, learning becomes easy and meaningful for students.

Learning without pressure is a learning process that does not contain threats or pressure on students. This pressure is not a pressure for learning. There are some exceptions of 
pressure, such as memorization, examination, and advice which can be considered pressure for students. These kinds of pressure remain students on a positive learning path. This is also reflected in Islamic education learning at Tamanan State Elementary School.

In addition, after listening to what students say, the teacher will provide explanations and guidance to students. Apart from that, the teacher also connects it with the daily life of society. The fact-based method is suitable for students. The goal is they can perfectly think to understand many problems in their environment in real terms, not just theory. This method can also help students process their thinking, so that, they can integrate theory and field practice.

As Muhibbinsyah explains in his book Educational Psychology, the most relevant learning to help and develop the potential of students is contextual learning (CTL). However, learning relates the material to conditions or facts in everyday life, which allows students to actualize into concepts that correspond to individual problems (Mujib and Suyadi 2020).

Periodically, in the learning process of Islamic education teachers at Tamanan State Elementary School no longer use the lecture learning method because, in that method, students seem lazy and bored. For this reason, learning has been replaced by various methods, such as snow bolling, problem-solving, and studying outdoors or outside the classroom. What stands out the most in Tamanan State Elementary School is the giving of responsibility and trust to students, such as class pickets which not only sweep, but tidy up and clean daily utensils such as plates, glasses, and other utensils.

This is because the teachers believe that learning is not only about memory, but many activities can also be applied in learning. One of the activities is changing students' thoughts in a direction that is in accordance with human nature. These changes are expected to lead to changes in a more positive area. The changes referred to include learning media, environmental changes, behavioral skills, skills, attitudes, responsiveness, acceptance, and abilities (Prayogo and Suyadi 2019).

The role of the teacher at Tamanan State Elementary School is more dominant as a very humane companion. This can be seen from various activities, including (1) emotional response to students, (2) the implementation of student creativity in the interactive design process, (3) good communication with students, (4)) tolerant interactions with each other; (5) consistency between student and teacher behavior; (6) Understanding the students' way of thinking; (7) Smiling to students (Sukmadinata and Sayodih 2005). 
In addition, the classrooms at Tamanan State Elementary School also display Islamic education-themed boards and pictures of the Prophet and Apostles or the names of angels. Students can see it as a form of increased motivation in terms of interest in studying Islamic education. Hopefully, it will be able to create space for students' visual satisfaction. Explicitly, all the methods and approaches taken are very helpful in applying students' understanding of religion, because if school is fun, learning will also run harmoniously. Teachers at Tamanan State Elementary School hope that the existing concept can provide a good atmosphere for students, Islamic learning in the classroom, and daily life.

All of these methods are also expected to be able to help students to actualize their existing potential, so that, they can solve problems faced in their lives. This is because learning is also defined as a process of thinking, feeling, and moving which can shape behavior, and increase knowledge and technology. Learning can be also someone's skill and work. Therefore, learning is also a process of individual development of the environment and social interactions (Mujib and Suyadi 2020).

\section{The Advantages and Disadvantages of Maslow's Theory in Learning}

In general, Maslow's theory is very useful. It has many advantages. However, in its application it has drawbacks. This is very reasonable. If summarized, the advantages of Maslow's theory in learning are: 1) Helping educators know the needs of students to make it easier to determine an appropriate learning plan. 2) Helping educators know about themselves, so that, the actualization in learning is also felt by educators. 3) Make it easier for educators to solve problems in the classroom related to student enthusiasm and motivation.

Then as the theory in general, in its application, this theory also has several shortcomings, especially when applied to Tamanan State Elementary School, they are: 1) To be able to understand the subject of students, teachers must have high intrapersonal intelligence, and not all teachers have this. 2) Awareness of using a variety of educational methods is still quite minimal so that teachers tend to use old methods and methods of learning. 3) because Maslow's theory is not specifically about education, especially Islamic education, this theory requires the help of other methods to be applied in learning as a whole.

In the end, as educators, they are expected to have creativity, innovation, and variety in learning. Every learning method or strategy has advantages and disadvantages. An educator is expected to be able to choose and sort methods according to the conditions because the best method is a method that is in accordance with the demands of the times and the needs of students (Elihami and Syahid 2018; Zafi 2020). The advantages of Maslow's theory, when 
applied to education, are similar to the benefits of the inquiry method. They are to provide students with real and creative learning experiences (Nur and Ichsan 2019).

\section{Conclusion}

Maslow's theory can be applied to Islamic education and has quite good benefits. To achieve this, before presenting the material, the teacher must first explain the learning objectives so that students have an interest and understand what benefits when studying it. Teachers must also often apply learning to life or simply provide insight that what is learned is what is needed in society. In principle, teacher is a role model, meaning that the teacher must be an example for his students to do good things, and in the good way.

If this theory is applied appropriately, it will have several benefits, including: 1) Helping educators know the needs of students. 2) Helping educators know about themselves. 3) Make it easier for educators to solve problems in the classroom related to student enthusiasm and motivation. 4) Make students learn without pressure, be brave, and know the benefits of what is being learned. The application of this method to education has had a fairly good impact, but still, all theories have flaws. The author strongly recommends using a combination of several educational theories that are tailored to the needs of the learning process. 


\section{REFERENCES}

Amalia, Aam. 2019. "Aplikasi Teori Kebutuhan Maslow Dalam Pembelajaran Bahasa Arab (Implementasi Pendekatan Humanistik).” Edulab: Majalah Ilmiah Laboratorium Pendidikan 4 (2): 25-42.

Arbayah. 2013. "Model Pembelajaran Humanistik." Dinamika Ilmu 13 (2): 220.

Assegaf, Abdur Rahman, and Dkk. 2007. Pendidikan Islam Di Indonesia. Yogyakarta: UIN Suka Press.

Azra, Azyumardi. 2012. Tradisi Dan Modernisasi Di Tengah Tantangan Milenium III. Jakarta: Kencana Prenamedia Grup.

Baharuddin, and E.N. Wahyuni. 2007. Teori Belajar Dan Pembelajaran. Yogyakarta: Ar-Ruzz Media.

Chatib, Munif. 2013. Kelasnya Manusia, Memaksimalkan Fungsi Otak Belajar Dengan Manajemen Display Kelas. Bandung: PT Mizan Pustaka.

Elihami, and Abdullah Syahid. 2018. "Penerapan Pembelajaran Pendidikan Agama Islam Dalam Membentuk Karakter Pribadi Yang Islami.” Edumaspul - Jurnal Pendidikan 2 (1): 79-96. https://doi.org/10.33487/edumaspul.v2i1.17.

Goble, Frank G. 1987. Mazhab Ketiga: Psikologi Humanistik Abraham Maslow. Edited by A. Supratiknya. Terj. Yogyakarta: Kanisius.

Iskandar. 2016. "Implementasi Teori Hirarki Kebutuhan Abraham Maslow Terhadap Peningkatan Kinerja Pustakawan." Jurnal Ilmu Perpustakaan, Informasi, Dan Kearsipan Khizanah Al-Hikmah 4 (1): 24-34.

Khamda, and Dkk. 2012. Strategi Pembelajaran Pendidikan Agama Islam Di Sekolah (Teori, Metode, Dan Implementasi. Yogyakarta: Idea Press.

Mappasiara. 2018. "PENDIDIKAN ISLAM (Pengertian, Ruang Lingkup Dan Epistemologinya).” Jurnal Pendidikan Islam VII (1): 147-60.

Maragustam. 2018. Filsafat Pendidikan Islam Menuju Pembentukan Karakter. Yogyakarta: Pascasarjana FITK UIN Sunan Kalijaga.

Maslow, Abraham H. 1970. MOTIVATION AND PERSONALITY. New York: Harper \& Row.

Muamanah, Hidayatul;, and Suyadi. 2020. "Pelaksanaan Teori Belajar Bermakna David Ausubel Dalam Pembelajaran Pendidikan Agama Islam.” Belajea: Jurnal Prndidikan Islam 5 (01): 23-36. https://doi.org/10.29240/belajea.v5.

Muhaimin. 2002. Paradigma Pendidikan Islam: Upaya Mengaktifkan Pendidikan Agam Islam Di Sekolah. Bandung: PT. Remaja Rosdakarya. 
Mujib, Zulfikar, and Suyadi. 2020. “Teori Humanistik Dan Implikasi Dalam Pembelajaran PAI Di SMA Sains Alquran Yogyakarta.” Jurnal Pendidikan Islam 4 (1): 11-23.

Nur, Syamsiah, and Muhammad Ichsan. 2019. "INOVASI PEMBELAJARAN "SUATU METODE PEMBELAJARAN PAI BERBASIS INQUIRY”.” Jurnal Al-Liqo: Prodi PAI STAI Auliaurrasyidin Tembilahan 04 (01): 1-14.

Prayogo, Eko, and Suyadi. 2019. "Pembelajaran Pendidikan Agama Islam Di Era Revolusi 4.0. Dengan Pendekatan Humanistik Di SMP Muhammadiyah Al Mujahidin Gunung Kidul.” At-Tarbiyat: Jurnal Pendidikan Islam 2 (2): 186-99.

Rachmahana, Ratna Syifa'a. 2008. "Psikologi Humanistik Dan Aplikasinya Dalam Pendidikan.” El TArbawi: Jurnal Pendidikan Islam I (1): 99-114.

Ramaylus. 2008. Ilmu Pendidikan Islam. Jakarta: Kalam Mulia.

Santrock, and Jhon W. 2009. Psikologi Pendidikan. Edited by Diana Angelica. Terj. Jakarta: Salemba Humanika.

Siregar, Eveline, and Hartini Nara. 2011. Teori Belajar Dan Pembelajaran. Bogor: Ghalia Indonesia.

Sukmadinata, and Nana Sayodih. 2005. Landasan Psikologi Proses Pendidikan. Bandung: Remaja Rosdakrya.

Sumantri, Budi Agus, and Nurul Ahmad. 2019. "TEORI BELAJAR HUMANISTIK DAN IMPLIKASINYA TERHADAP PEMBELAJARAN PENDIDIKAN AGAMA ISLAM.” Fondatia: Jurnal Pendidikan Dasar 3 (2): 1-18.

Umam, Muchammad Chairul. 2019. "IMPLEMENTASI TEORI BELAJAR HUMANISTIK CARL R. ROGERS PADA PEMBELAJARAN PENDIDIKAN AGAMA ISLAM.” Tadrib: Jurnal Pendidikan Agama Islam 5 (2): 247-64.

Zafi, Ashif Az. 2020. "Pemahaman Dan Penghayatan Peserta Didik Tentang Ibadah Dalam Pembelajaran Fiqih Di MI Manafiul Ulum Gebog Kudus.” Elementary: Jurnal Ilmiah Pendidikan Dasar 6 (1): 47-58. https://doi.org/10.32332/ELEMENTARY.V6I1.1692.

Zainab, Nurul. 2020. "Rekonstruksi Kurikulum Pendidikan Agama Islam: Analisis Model Kurikulum Rahmatan Lil Alamin.” Tadris: Jurnal Pendidikan Islam 15 (2): 168-83. https://doi.org/10.19105/tjpi.v15i2.4022. 
